\title{
Quantity and quality of groundwater resources distribution along Sirdarya province, Uzbekistan
}

\author{
Rashid Kulmatov ${ }^{1 *}$, Sarvar Odilov ${ }^{1}$, Sayidjakhon Khasanov ${ }^{2,3,4,5}$, and Rustam Allaberdiev ${ }^{1}$ \\ ${ }^{1}$ National University of Uzbekistan named after Mirzo Ulugbek, Tashkent 100174, Uzbekistan \\ ${ }^{2}$ Key Laboratory of Ecosystem Network Observation and Modeling, Institute of Geographic Sciences \\ and Natural Resources Research, Chinese Academy of Sciences, Beijing 100101, China \\ ${ }^{3}$ University of Chinese Academy of Sciences, Beijing 100049, China \\ ${ }^{4}$ Tashkent Institute of Irrigation and Agricultural Mechanization Engineers, Tashkent 100000, \\ Uzbekistan \\ ${ }^{5}$ Tashkent State Agrarian University, Tashkent province 100174, Uzbekistan
}

\begin{abstract}
In the current context of climate change, water resources are an important source of the economy of Uzbekistan. The article assesses the climatic conditions of Sirdarya province for 2006-2018, groundwater resources for 2010-2018, their efficient use, the chemical composition of groundwater (chlorine and sulfate from anions, $\mathrm{Cu}, \mathrm{Be}, \mathrm{Mo}, \mathrm{As}, \mathrm{Pb}, \mathrm{Se}$ from harmful heavy metals and Sr). Analysis of the time and space distribution of the amount of heavy metals in the groundwater of the province showed that their amount did not exceed the allowable limit. Changes in the amount of groundwater used for drinking, irrigation, industrial and technical purposes in the province were identified and evaluated, as well as scientific and practical recommendations for sustainable use and protection of groundwater resources.
\end{abstract}

\section{Introduction}

Water scarcity worldwide has become a global threat, leading to the deterioration of the natural environment, limited living opportunities and worsening public health $[1,2]$. Today, more than 2 billion people living in more than aridic and semi-aridic countries of the planet suffer from water shortages [2-4]. The global increase in average annual temperature in the last quarter of the 20th century caused gradual changes in precipitation and evaporation rate, which in turn fostered an average annual increase or decrease in surface and groundwater [5,6]. Groundwater utilization as a fresh drinking water in the water scarce regions is increasing year by year, and simultaneously there are several difficulties in meeting the basic food needs of the population of many countries and the level of water supply necessary to maintain regional ecosystems [4-6].

Climate change affects hydrological processes, so precipitation, evaporation, snowfall and melting affect the formation and formation of groundwater. This in turn has a negative impact on ecosystems [7]. Climate change and variability have a direct and indirect impact on the quantity and quality of groundwater. In the context of climate change, groundwater

* Corresponding author: rashidkulmatov46@gmail.com 
is critical to global food security. In addition, climate change will lead to a decrease in crop species and yields, leading to increased poverty in low-income countries [7-10].

Groundwater is the second largest water body in the hydrosphere after the world oceans, and their study is of great scientific and practical importance [11-14]. Groundwater is an important part of the hydrological cycle and accounts for $97 \%$ of surface freshwater [12]. Currently, only $20 \%$ of the global water needs are encountered by groundwater, of which $70 \%$ is for irrigation, $21 \%$ for domestic use (including drinking water), and $9 \%$ for industry or mining [13].

\subsection{Global groundwater use}

Russia is a country with huge water resources potential. In terms of reserves, Russia accounts for $20 \%$ of the global freshwater resources (excluding glaciers and groundwater). In Russia, in the 1960-80s, a large amount of groundwater was in-depth studied and its reserves amounted to 85 million tons $[14,15]$.

In many European countries, such as Austria, Belgium, Hungary, Lithuania, Germany, Belarus, Denmark, Romania, Switzerland and the former Yugoslavia, the share of groundwater used for domestic and drinking purposes is more than $70 \%$, while in Bulgaria, France, Italy, the Netherlands, Portugal, Czechia, and Slovakia, this amount is 50-70\% [1416]. To pinpoint such countries among them, the groundwater monitoring network in Bulgaria includes 508 monitoring points: 106 springs, 340 deep and shallow wells, and 62 pumping stations. The analyzes of groundwater targeted to investigate water $\mathrm{pH}$ value, temperature, electrical conductivity, mineralization $\left(\mathrm{HCO}_{3}, \mathrm{NO}_{3}, \mathrm{NO}_{2}, \mathrm{NH}_{4}, \mathrm{PO}, \mathrm{Ca}, \mathrm{Mg}\right.$, $\mathrm{Na}, \mathrm{K}, \mathrm{SO}_{4}, \mathrm{Cl}, \mathrm{Mn}$, and $\mathrm{Fe}$ ), water total hardness, and dissolved oxygen content in water from chemicals [17]. In Denmark, drinking water is used almost exclusively from groundwater. Changes in the amount of groundwater for drinking purposes are made in about 100 wells, and the monitoring of changes in quality is carried out in 73 monitoring sites. Groundwater mineralization $\left(\mathrm{NO}_{2}, \mathrm{NO}_{3}, \mathrm{NH}_{4}, \mathrm{Ca}, \mathrm{Na}, \mathrm{Mg}, \mathrm{K}, \mathrm{HCO}_{3}, \mathrm{Cl}, \mathrm{SO}\right.$, $\mathrm{Fe}$, and $\mathrm{Mn}$ ), organic carbon, total $\mathrm{P}$, and aggressive carbon dioxide are determined from groundwater samples taken on the basis of established European programs [17].

Groundwater resources play an important role in supporting the economic and social development of the People's Republic of China in the context of climate change. The amount of surface water in this country is 2.68 trillion $\mathrm{m}^{3}$, and the amount of groundwater is 0.81 trillion $\mathrm{m}^{3}$. The annual natural production of fresh groundwater in China is 0.88 trillion $\mathrm{m}^{3}$, accounting for about $31 \%$ of total water resources of China $[18,19]$.

Nepal, located in South Asia, is one of the richest countries in terms of water resources. Regarding the water resources in the Himalayas, there are more than $480 \mathrm{~km}^{3}$ of glaciers in an area covered by about $5,000 \mathrm{~km}^{2}$ of glaciers. The total amount of renewable water resources is $237 \mathrm{~km}^{3} /$ year, and the amount of available groundwater is $12 \mathrm{~km}^{3} /$ year. Groundwater is available in many parts of the country, but the amount and depth could vary region by region. Currently, only $22 \%$ of the country's available groundwater in the lowlands is being developed and the quality of the groundwater used is generally commensurate with the purpose of irrigation and drinking [20].

\subsection{Importance of water resources in Central Asia and Uzbekistan}

Water resources are one of the key factors in the socio-economic well-being of the Central Asian states and the protection of the environment [10,21]. The total area of irrigated lands in Central Asia is 7,795 million hectares and water resources are mostly in agriculture and mainly for irrigation (80-90\%). However, there are significant water losses in agriculture due to the low efficiency of most irrigation water systems in the region [10, 21-24]. 
Due to the rapid development of agricultural and industrial enterprises, this upsurge development leads to changes in the quality and quantity of available groundwater resources [25]. The use of groundwater for irrigation purposes in irrigated areas in agriculture has experienced a gradual decline in the amount of water in transboundary aquifers in Central Asia [26].

Among Central Asian countries, Kyrgyzstan and Tajikistan are rich in surface water resources and do not use groundwater resources to a lesser extent. Turkmenistan's GWR are limited and account for $2.5 \%$ of all water resources. Kazakhstan and Uzbekistan, located in the lower reaches of the Amudarya, Syrdarya and Zarafshan river basins, have relatively low surface and groundwater resources and are highly dependent on groundwater [27, 28]. Groundwater together with surface water bodies forms the state water fund of the Republic of Uzbekistan [29].

Water scarcity is one of the main factors that can negatively affect the sustainable development of Uzbekistan. Uzbekistan is one of the countries in the region, having a high demand for water resources to meet the growing socio-economic and environmental needs of the population and natural ecosystems, to ensure sustainable development $[30,31]$. In recent years, Uzbekistan has encountered water scarcity, depletion of water resources and pollution. The local economy, as well as environmental stability depends in many respects on the available surface and groundwater resources, and their quantity and quality indicators $[5,32,33]$.

Groundwater is a part of the country's water resources and plays an important role in providing the population with drinking water, irrigation of agricultural lands and pastures $[31,32,34]$. Most of studies have been carried out in a short period of time, and the data for the next ten years on determining the quality and quantity of groundwater and its use in the economy have not been sufficiently taken into account.

The peculiarity of Sirdarya province of Uzbekistan is the development of various interconnected hydrogeological transboundary water reserves and strata. By analyzing long-term monitoring of changes in the quality and quantity of groundwater, it is important to know the purpose of use, but it is not yet qualified in Sirdarya province. The study of regional groundwater resources is also important because it is a reliable source of basic drinking water supply for the population and is widely used in the economy.

Considering all the aspects above, the purpose of this study was to determine, for the first time, the quantity and quality of existing GWR in Sirdarya province for the period 2010-2017 with reference to the analysis of provincial climate change.

\subsection{Groundwater in Uzbekistan}

There are 95 groundwater resources (GWR) in Uzbekistan. According to the State Geological Committee as of January 2011, the natural reserves of groundwater in Uzbekistan amounted to 75.6 million $\mathrm{m}^{3}$ per day [35]. Groundwater is an important source of water in Uzbekistan, since 13.3 million $\mathrm{m}^{3}$ per day for drinking water supply of the country (in 2010), industrial and technical water supply -2.13 million $\mathrm{m}^{3}$ per day, for irrigation of crops and pastures -1.3 million $\mathrm{m}^{3}$ of groundwater were used. In most cases, these groundwater resources comply with the hygienic requirements and quality control of drinking water in accordance with the State Standards of Uzbekistan 2000-950 (UzDSt). In Uzbekistan, groundwater sources provide an average of $60 \%$ of drinking water consumed by the population. There are more than 25,000 groundwater wells in Uzbekistan and the total volume of groundwater with a salinity of less than $1 \mathrm{~g} / 1$ is $9.13-9.49 \mathrm{~km}^{3}$ per year [31, 36]. The total regional GWR of the country is estimated at around $24 \mathrm{~km}^{3}$. According to the results of such studies on state monitoring of groundwater in 2015, 357 GWR were identified in the territory of Uzbekistan and 267 GWR were approved [37]. 
Groundwater resources used as fresh drinking water are $34.5 \%$ in the Fergana Valley, $28.5 \%$ in Tashkent, $13.1 \%$ in Samarkand, and $13.1 \%$ in Surkhandarya provinces [38]. In the remaining areas, fresh GWR are estimated at around $7 \% .1,142 \mathrm{~km}^{3}$ of groundwater is used annually to provide urban population with drinking water, and $1,423 \mathrm{~km}^{3}$ of groundwater is used in rural areas [24, 28]. However, in the last decade, the quality of groundwater has deteriorated and as a result, GWR that can be used as a source of drinking water have decreased. In the western part of the country (in the lower reaches of the Zarafshan River and in the western part of the Kashkadarya, Syrdarya, Amudarya and Central Kyzylkum basins), GWR are highly mineralized and hard. Fresh groundwater used for drinking water supply in Bukhara and Khorezm provinces and the Republic of Karakalpakstan formed along large watercourses (Amudarya and irrigation canals) does not meet state standards for use as drinking water due to its high mineralization and poor quality in the last 10-15 years [36-39].

Of the 133 groundwater wells with balneological activity in Uzbekistan, 119 contain physiologically active components (bromine, boron, silica, iodine, radon, hydrogen sulfide, and iron), salts, gas mixtures, and high temperatures (as of 2019). These groundwater wells are used by resorts, sanatoriums, dispensaries, rest homes, physiotherapy clinics, and mineral water plants $[36,38]$.

Since 1995, 150 hydrogeological stations in almost all regions have been monitoring groundwater status. The monitoring system covers 99 national aquifers and reservoirs, 1,671 wells and 43 springs, and consists of 1,074 monitoring stations equipped with automated technology [38, 39]. To adequately improve the protection of existing and potential sources of drinking water in the country, 10 zones of fresh groundwater formation have been granted the status of 'Protected Natural Areas of National Importance' [38].

Currently, 19 GWR in Uzbekistan are located across borders, bordering or between two or more countries. Uzbekistan shares twelve GWR with neighboring countries. Therefore, the rational and sustainable use of transboundary groundwater in the country is extremely important.

\section{Materials and methods}

\subsection{Study area}

Sirdarya province is located in the eastern part of Uzbekistan, with an area of $4,300 \mathrm{~km}^{2}$ (Fig. 1) and shares borders with Kazakhstan to the north, followed by Tashkent province to the east, the Tajikistan to the south, and Jizzakh province to the west. The administrative center of the province is the city of Gulistan. The province composes of eight administrative districts (Sardoba, Boyovut, Gulistan, Khavas, Mirzaabad, Sayhunabad, Okoltin, Syrdarya) and a number of cities such as Gulistan, Syrdarya, Yangier, Bakht, Shirin (Fig. 1).

As of October 2019, the population of the province is 841,800 people. Of these, 359,500 people live in urban and metropolitan areas and 482,300 people in rural areas. The population density is 196.7 people per $\mathrm{km}^{2}$ [35].

Mirzachul steppe takes a large part of the province. The relief is mainly a wavy plain, descending from south to northwest. There are such plains as Shorazak, Mirzaabad, Sardoba. Part of the plain is formed by riverbeds, some of which are occupied by lakes, swamps and saline soils. New artificial canals and ditches have been dug across the province; deserts and such rangelands have been developed and turned into arable lands. New irrigation facilities have been built in the plains, including cotton fields, orchards and vineyards. The hills consist of arable lands and pastures. The soils are mostly light gray 
soils with low to moderate salinity [40]. Due to strong evaporation in summer, groundwater salinizes the soil of surface areas in Sirdarya province [41].
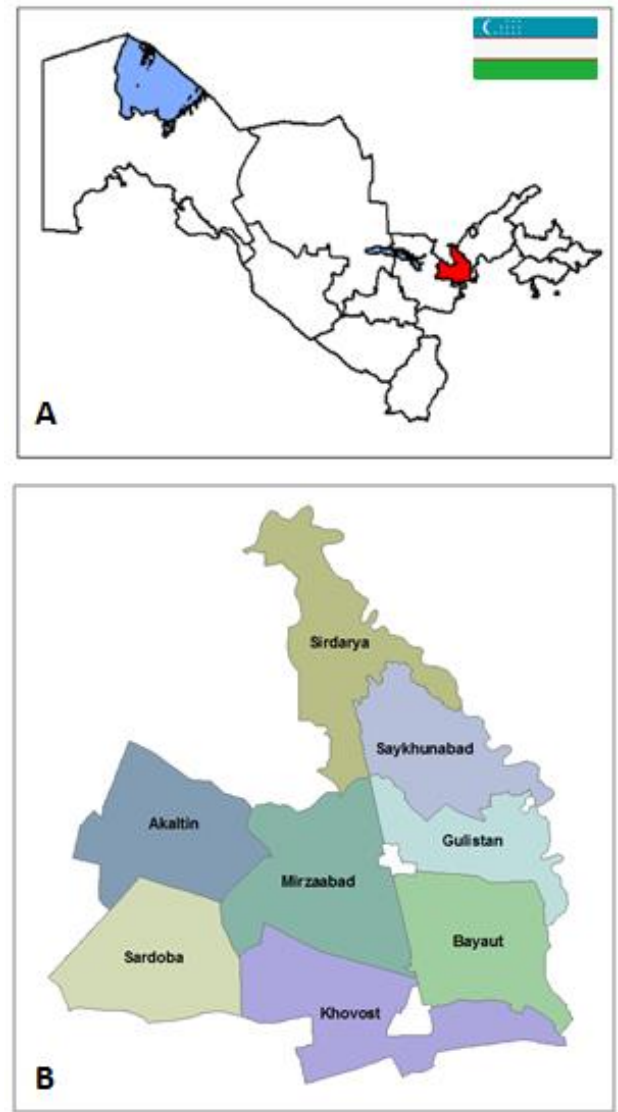

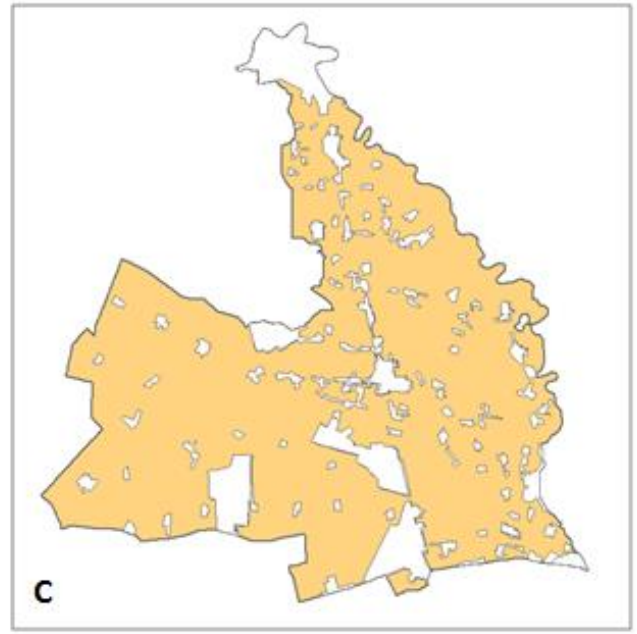

A Map of Uzbekistan

B Administrative map of Syrdarya

C Agricultural map of Syrdarya

\section{Land use}

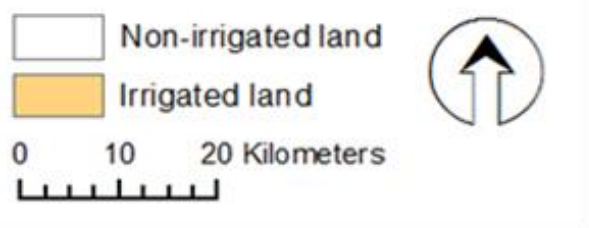

Fig. 1. Map of the study site

\subsection{Climate}

The climatic conditions of the province are sharply continental, characterized by dry and roasting summers. Precipitation is mainly observed in winter and spring. Often a hot wind (garmsel) blows and dries out a third of the Soil surface, adversely affecting plant development [42].

There are three, namely Syrdarya, Okoltin and Yangier, differently located meteorological stations in the province, so we can feasibly triangulate the dynamics of change in average annual air temperature and annual precipitation varies at different meteorological stations (Fig. 2) [43]. If we look closer at the meteorological data, from 2007 to 2017 the highest average annual temperature in the province was $16.6^{\circ} \mathrm{C}$ in 2016 observed in the Yangier meteorological station, and the lowest was $13.7^{\circ} \mathrm{C}$ at the Syrdarya meteorological station in 2014. During the study years, the average annual temperature at the Syrdarya meteorological station was $14.8^{\circ} \mathrm{C}$, the highest $-15.8^{\circ} \mathrm{C}$ in 2016 and the lowest $-13.7^{\circ} \mathrm{C}$ in 2014 , the average annual temperature at the Ak-altin meteorological station was $15.4^{\circ} \mathrm{C}$, the highest $-16.5^{\circ} \mathrm{C}$ in 2016 and the lowest $-14.4^{\circ} \mathrm{C}$ in 2008 , the average annual 
temperature at the Yangier meteorological station was $15.4^{\circ} \mathrm{C}$, the highest $-16.6^{\circ} \mathrm{C}$ in 2016 and the lowest $14.4^{\circ} \mathrm{C}$ in 2014 (Fig. 2).

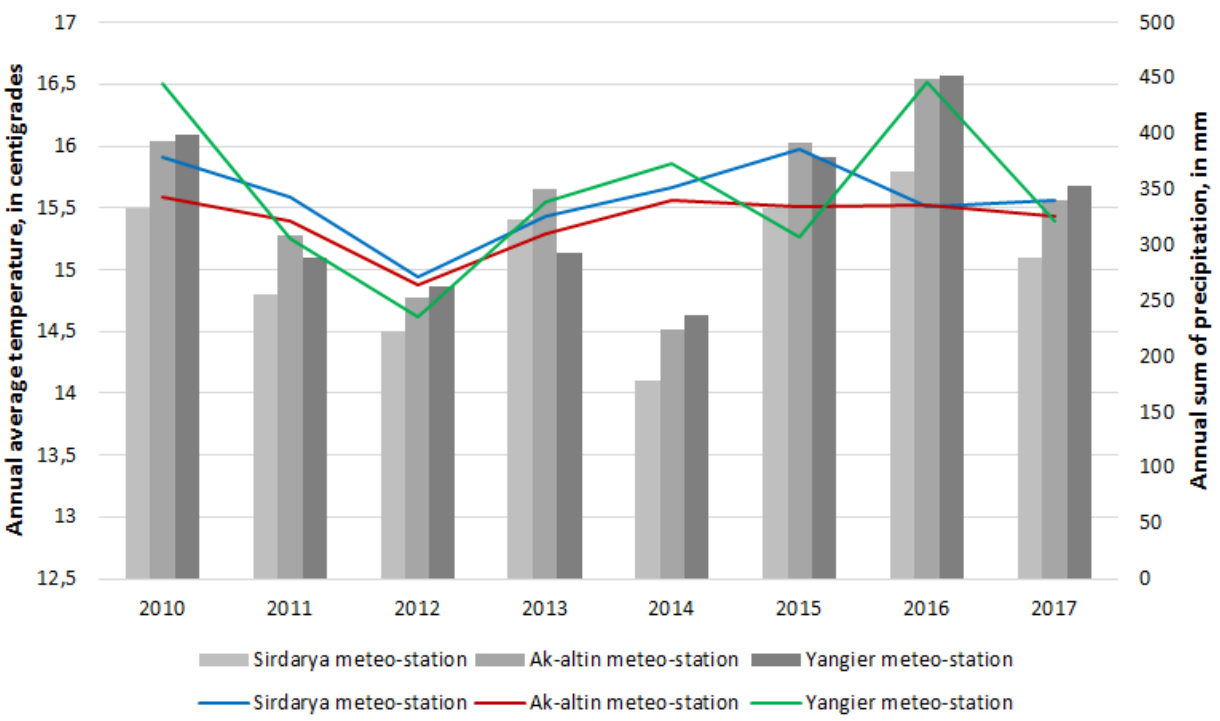

Fig. 2. Dynamics of long-term average air temperaturesand precipitation in Sirdarya province (bars for temperature and lines for precipitation)

The largest amount of precipitation in the province received in the winter and spring months. The highest and lowest precipitation rates among meteorological stations in the province between 2007 and 2017 were observed at the Yangier meteorological station, with the largest amount being $447 \mathrm{~mm}$ in 2016 and the smallest amount in 2012 being $236 \mathrm{~mm}$ (Fig. 2). The rainiest year in the study years was 2010 and the lowest rainy was in 2012.

The main reason behind paying more attention to the climate of the province is that the hydrometeorological data shows a direct impact on the quantity and quality of groundwater.

\subsection{Methodology}

The study used the database of the Uzhydromet Center of the Republic of Uzbekistan and the provincial Hydrometeorology Department [43]. Indicators of hydrometeorological changes in Sirdarya province were used from the data of Syrdarya, Okoltin and Yangier meteorological stations located in the province, and the data were processed in-depth statistics. Besides that, data of the State Enterprise "Institute of Hydrogeology and Engineering Geology" of the State Committee of the Republic of Uzbekistan for Geology and Mineral Resources, which controls the state monitoring and rational use of groundwater in Uzbekistan, was also used [44, 45].

Field expeditions to the research area in 2019-2020 were conducted to obtain specific information about the provincial GWR (Fig. 3). During the special field expedition, water samples were taken from Ahunbabaev, Beshbulak, Bakht, Sardoba-I, Gulistan-II, and Mirzachul water intake facilities (WIF) to compare the quality of groundwater with the permissible norms (PN). Quality indicators of groundwater samples were determined in the laboratory "Hydrochemistry" of the State Unitary Enterprise "Uzbekhydrogeology". Approximately 1.5 liters of water from each point was collected in a clean plastic container and the samples were stored in a $4{ }^{\circ} \mathrm{C}$ refrigerator prior to analysis. Mineralization of water samples, total hardness, chlorine and sulfate content were analyzed using the methodology 
developed by A.A. Reznikov (1970) [46, 47]. In addition, samples were brought to $\mathrm{pH}=2$ using chemically pure nitric acid to determine heavy metals. Chlorine, sulphate, photometric composition of groundwater, and heavy metals $(\mathrm{Cu}, \mathrm{Be}, \mathrm{Mo}, \mathrm{As}, \mathrm{Pb}, \mathrm{Se}$ and $\mathrm{Sr}$ ) were determined by atomic absorption method (AAS: Perkin Elmer Analyst 100).
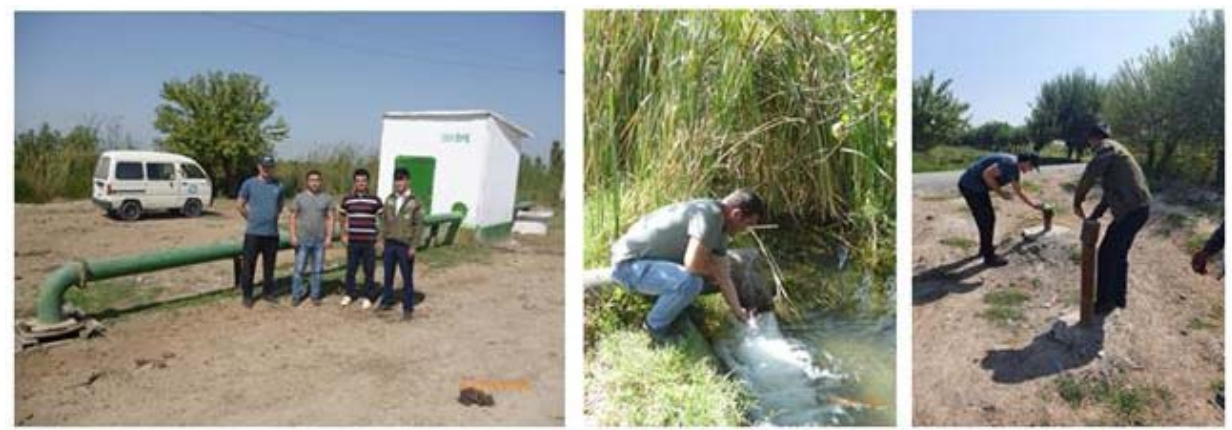

Fig. 3. Excerpts from field expeditions organized to the study area: a) acquaintance of field expedition members with vertical wells; b) the place where groundwater is discharged into the economic canal through vertical wells; c) groundwater monitoring observation points.

\section{Results and discussion}

\subsection{Provincial groundwater resources}

There are Khavas, Syrdarya, Central and Dustlik GWR (GWR) in the province (Fig. 4). Khavas GWR is light yellow in Fig. 4, with an area of $430 \mathrm{~km}^{2}$. Part of the reserve is located in Jizzakh province. The field is located in the Mirzachul hydrogeological zone and in the southern part of the province. The Syrdarya GWR is shown in blue in Fig. 4 and is located in the north-eastern part of the province with an area of $1,390 \mathrm{~km}^{2}$. The reserve is bordered by the Central Groundwater Field in the south, the Syrdarya River and Tashkent province in the north and east, and the Republic of Kazakhstan in the northwest.

The central GWR is located in the central part of the province and extends from southeast to northwest. The total area of the reserve, represented in light green in Fig. 4, is $1,490 \mathrm{~km}^{2}$. The reserve is bordered by the Syrdarya River Basin in the east, the Republic of Kazakhstan in the northwest, and the Dustlik reserve in the southwest.

Dustlik GWR is represented in Fig. 4 in light red. The reserve covers part of Sardoba, Khavas and Okoltin districts in the western part of the province and the area is $1,680 \mathrm{~km}^{2}$. The GWR is bordered by Jizzakh province in the south-west and Central reserve in the north-east.

Plotting these GWR occupied territories into percentages, 34\% of the province's area, ie the largest part belongs to Dustlik GWR, 30\% to Central GWR, 28\% to Syrdarya GWR, and the smallest, $8 \%$, to Khavas GWR (Fig. 5).

The province's GWRs are $380,160 \mathrm{~m}^{3} /$ day at the Khavas reserve, $3,032,640 \mathrm{~m}^{3} /$ day at the Syrdarya reserve, and 3,434,720 $\mathrm{m}^{3} /$ day at the Central reserve. During 2014-2017, the provincial GWRs at the Dustlik reserve were not assessed. The presence of the Sardoba Reservoir on the territory of the Dustlik reserve reduces the possibility of assessing the water resources of this reserve. 


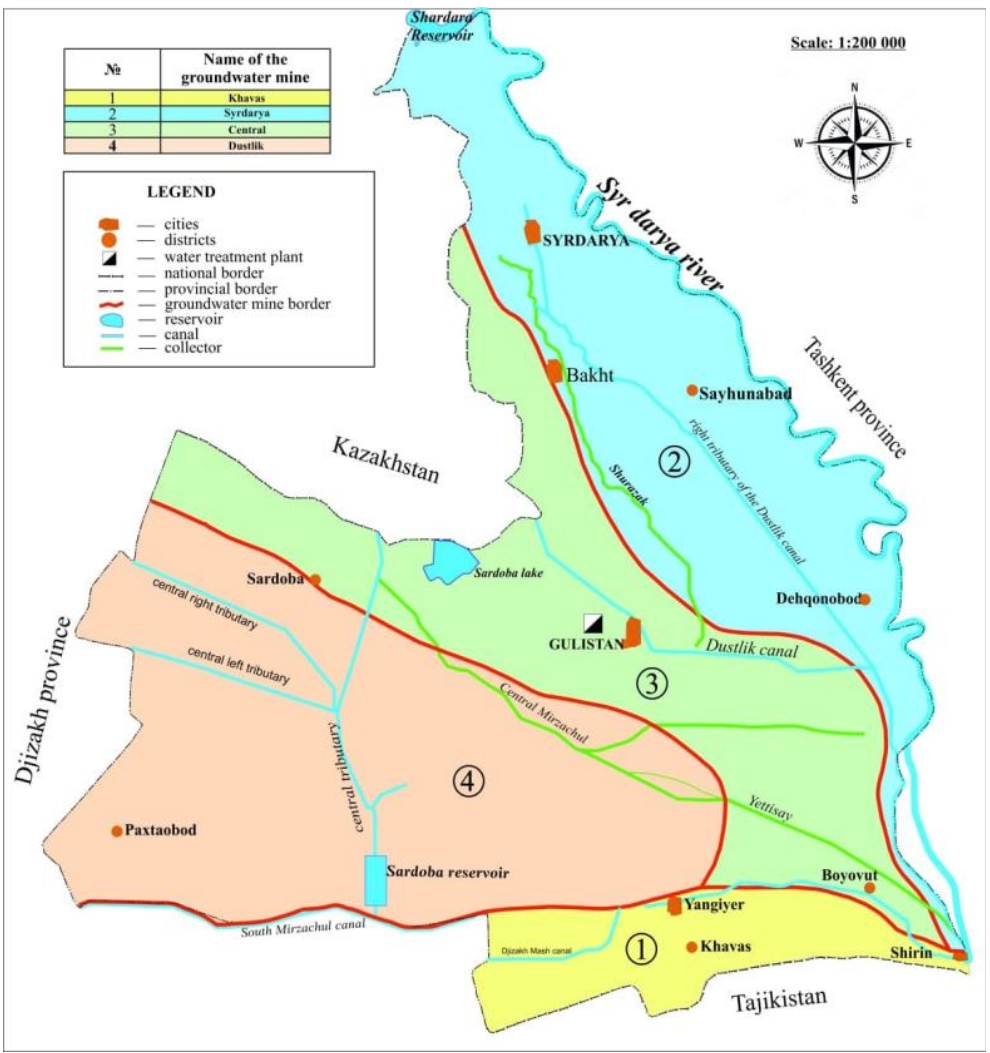

Fig. 4. Provincial GWR distribution.

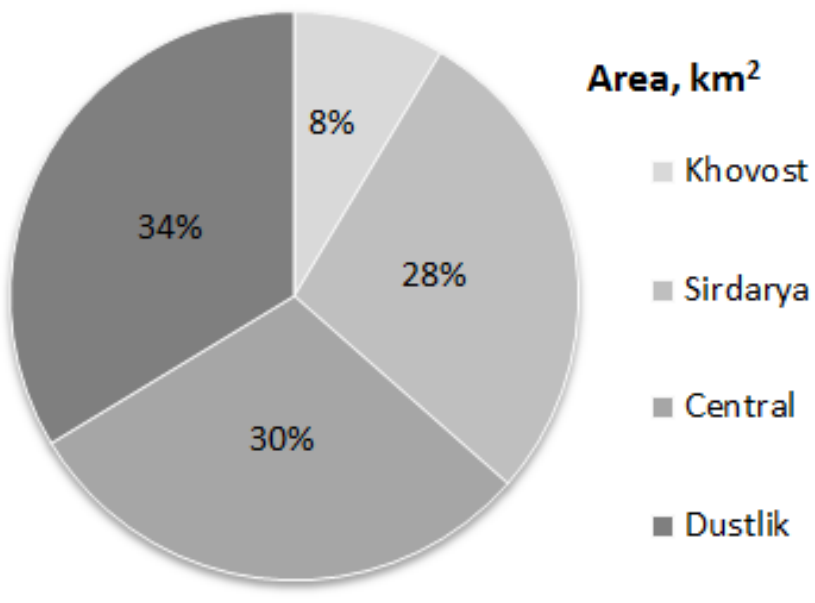

Fig. 5. Distribution of the total land area of the province according to GWRs.

Changes in groundwater resources in the province depend on climatic (precipitation, air temperature, evaporation), hydrological (river water consumption), biogenic (plant transpiration), and anthropogenic (irrigation, drainage, irrigation, groundwater use, etc.) factors [48]. In addition, the geological structure of the province is directly related to the geomorphological structure. 
The groundwater resources of the province are transboundary in nature. The Khavas, Central and Syrdarya GWRs share borders with the Republics of Kazakhstan and Tajikistan. Acquaintance and generalization of information on the groundwater of the neighboring state in determining the factors affecting groundwater resources, in turn, determines the opportunities for cooperation in the rational use and protection of groundwater resources.

\subsection{Chemical composition of groundwater}

Since most of the groundwater is used for drinking purposes by the population of the province, it is advisable to constantly monitor its chemical composition. At the same time, the definition and assessment of groundwater quality is based on the use of these water resources in the economy, the negative impact of natural and man-made resources over time, the links between large surface water bodies and GWRs, and the factors affecting it in transboundary groundwater layers. serves as a reliable source of detection and protection.

In determining and assessing the quality of groundwater in the province, the composition of water from Ahunbabaev, Beshbulak, Bakht, Sardoba-I, Gulistan-II, and Mirzachul WIFs were studied. Given the large number of observation points studying groundwater quality in the province, the large WIFs mentioned above were selected in the study of their quality and groundwater samples were then analyzed at the laboratory of the hydrochemistry of Uzhydromet, Uzbekistan (Fig. 6).
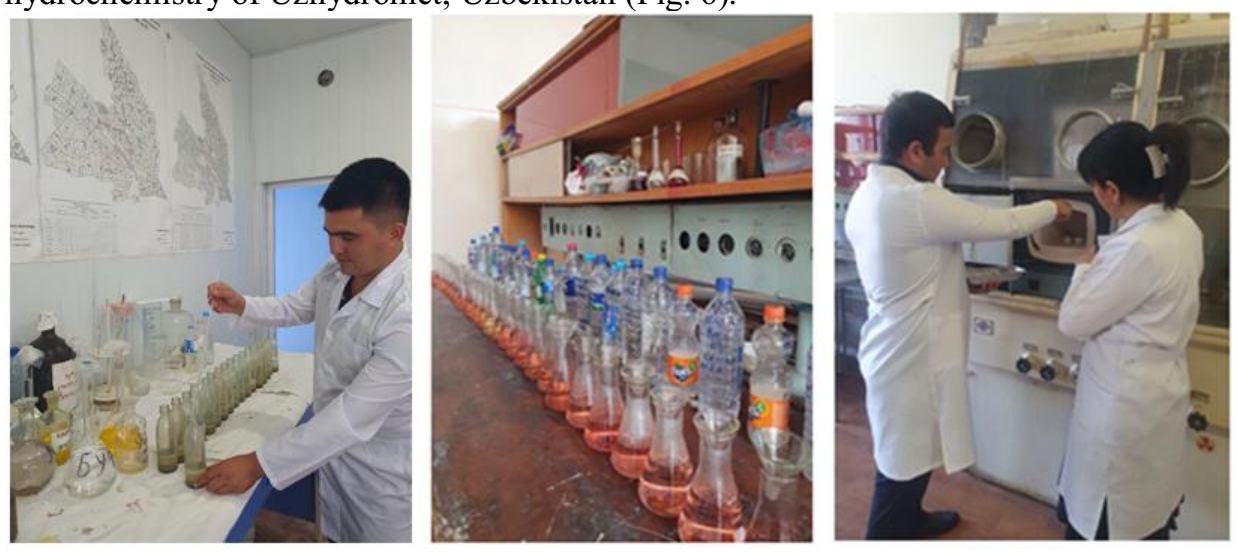

Fig. 6. Process of chemical analysis of groundwater in the laboratory "Hydrochemistry" of Uzhydromet, Uzbekistan.

Fig. 7 below shows the dynamics of changes in groundwater mineralization, total hardness, chlorine element and sulfate salts during 2010, 2013 and 2016.

The dynamics of changes in the amount of mineralization in the waters of Ahunbabaev, Beshbulak, Bakht, Sardoba-I, Gulistan-II, and Mirzachul WIFs during the years of study is shown in Fig. 7a.

Among these WIFs, Sardoba-I WIF has the highest mineralization, while Beshbulak WIF has the lowest mineralization. Given that the PN of water mineralization according to the hygienic requirements and quality control of drinking water according to the State Standards of Uzbekistan (UzDSt) is $1,000 \mathrm{mg} / \mathrm{l}$, the water mineralization of these WIFs does not exceed the PN. Monitoring results show that during the study years, the increase and decrease in the amount of mineralization in the water content of WIFs varied from 14.0 to $98.0 \mathrm{mg} / \mathrm{l}$ in $2010-2013$, and from 4.0 to $188.0 \mathrm{mg} / \mathrm{l}$ in $2013-2016$. The considerable changes were in the Sardoba-I WIF. This may be due to the proximity of the WIF to the 
settlement, the presence of surface irrigation networks and the poor reclamation of WIFs in the area.

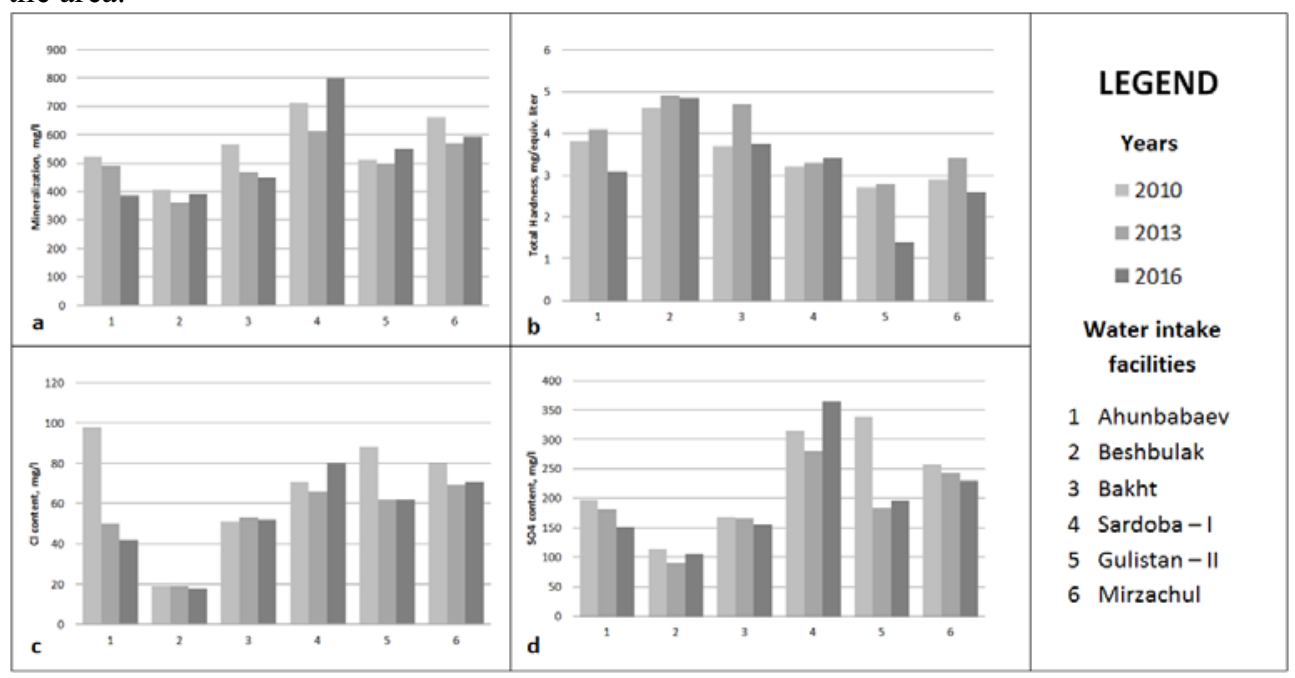

Fig. 7. Groundwater mineralization, total hardness and dynamics of changes in chlorine and sulfate content (2010-2016).

From 2010 to 2016, the analysis of the dynamic changes in the total hardness of Ahunbabaev, Beshbulak, Bakht, Sardoba - I, Gulistan - II, Mirzachul WIF showed that Beshbulak WIF has the highest water hardness, and Gulistan - II WIF has the lowest water hardness which is shown in Fig. 7b. Given that the total hardness of groundwater PN is 7.0 mg-eq/l, the total hardness of water in these WIFs did not exceed the PN. The increase and decrease of the total hardness of water in the period from 2010 to 2013 ranged from 0.1 to $1.0 \mathrm{mg}$-eq/l, and from 2013 to 2016 to 0.1 to $1.4 \mathrm{mg}$-eq $/ 1$.

Between 2010 and 2016, among Ahunbabaev, Beshbulak, Bakht, Sardoba-I, Gulistan-II, and Mirzachul WIFs, the lowest chlorine content was observed in Beshbulak WIF water, but the chlorine content of other WIF waters was closer (Fig. 7c). Given that the chlorine element's PN is $250.0 \mathrm{mg} / \mathrm{l}$, the amount of chlorine in this WIF water did not exceed the PN. Between 2010-2013, the increase and decrease in the amount of chlorine in the water ranged from 2.0 to $48.0 \mathrm{mg} / \mathrm{l}$, and from 2013 to 2016, it ranged from 1.0 to $14.0 \mathrm{mg} / \mathrm{l}$ (Fig. $7 \mathrm{c})$.

Regarding the analysis of the dynamic changes in the content of sulfates in the water of Ahunbabaev, Beshbulak, Bakht, Sardoba-I, Gulistan-II, and Mirzachul WIFs during the research years, the content of sulfates in Sardoba-I WIF water was the highest, whereas the content of sulfates in Beshbulak WIF water was the lowest (Fig. 7d). Given that the PN of sulfates in groundwater is $400.0 \mathrm{mg} / \mathrm{l}$, the amount of sulfates in the water of these WIFs did not exceed the PN. From 2010 to 2013, the increase and decrease of sulfates in groundwater ranged from 3.0 to $155.0 \mathrm{mg} / \mathrm{l}$, and from 2013 to 2016 to 10.0 to $85.0 \mathrm{mg} / \mathrm{l}$.

During the research years, the amounts of some heavy metals in the waters of Ahunbabaev, Beshbulak, Bakht, Sardoba-I, Gulistan-II, Mirzachul WIFs were compared with the PN (Table 1).

The amount of copper element in groundwater has varied slightly little over the years of the study and has not exceeded the PN. The copper element was not detected in Sardoba-I WIF in 2016, the largest amount was detected in 2013 in Gulistan-II, and the smallest amount was detected in 2016 in Beshbulak WIF.

The amount of beryllium element also did not exceed the amount of the PN. The largest amount of beryllium was detected in 2010 in Bakht, and the smallest in 2013 in Gulistan-II 
WIF. The largest amount of molybdenum was detected in 2010 in Gulistan-II, and the smallest in 2016 in Ahunbabaev and Beshbulak WIF. The amount of arsenic in groundwater was also found in the largest amount in 2010 in Bakht, and the smallest amount in 2016 in Beshbulak WIF. The amount of lead also did not exceed the PN, and the largest amount was detected in 2013 in Gulistan-II, and the smallest amount in 2013 in Ahunbabaev WIF. The amount of selenium did not exceed the amount of the PN, and the largest amount was detected in 2013 in Gulistan-II, and the smallest amount in 2016 in Bakht WIF. The largest amount of strontium was detected in 2010 in Sardoba-I and Gulistan-II, and the smallest amount in 2016 in Beshbulak WIF.

Table 1. Amount of some heavy metals in groundwater, $\mathrm{mg} / \mathrm{l}$.

\begin{tabular}{|c|c|c|c|c|c|c|c|c|c|}
\hline \# & $\begin{array}{l}\text { Name of water } \\
\text { intake facility }\end{array}$ & Year & $\mathrm{Cu}$ & Be & Mo & As & $\mathbf{P b}$ & $\mathrm{Se}$ & $\mathrm{Sr}$ \\
\hline \multicolumn{3}{|c|}{$\begin{array}{l}\text { Permissible Norm of the State } \\
\text { Standard of Uzbekistan }\end{array}$} & 1.0 & 0.0002 & 0.25 & 0.05 & 0.03 & 0.01 & 7.0 \\
\hline \multirow{3}{*}{1} & \multirow{3}{*}{ Ahunbabaev } & 2010 & 0.0069 & - & 0.005 & 0.0045 & - & 0.00051 & 1.3 \\
\hline & & 2013 & 0.0052 & 0.00004 & 0.0033 & 0.0049 & 0.00004 & 0.0061 & 0.8 \\
\hline & & 2016 & 0.0019 & 0.000026 & 0.0015 & 0.0023 & 0.0007 & 0.0032 & 0.75 \\
\hline \multirow{3}{*}{2} & \multirow{3}{*}{ Beshbulak } & 2010 & 0.0058 & - & 0.0034 & 0.0015 & - & 0.001 & 0.83 \\
\hline & & 2013 & 0.002 & - & 0.0019 & - & - & 0.0037 & 0.50 \\
\hline & & 2016 & 0.0009 & 0.000011 & 0.0015 & 0.0006 & 0.0002 & 0.00057 & 0.47 \\
\hline \multirow{3}{*}{3} & \multirow{3}{*}{ Bakht } & 2010 & 0.0068 & 0.00009 & 0.0033 & 0.0067 & 0.0016 & 0.0016 & 1.2 \\
\hline & & 2013 & 0.0031 & - & 0.003 & 0.0031 & 0.0003 & 0.0023 & 0.5 \\
\hline & & 2016 & 0.0007 & 0.000039 & 0.0036 & 0.0029 & 0.0007 & 0.00025 & 0.55 \\
\hline \multirow{3}{*}{4} & \multirow{3}{*}{ Sardoba - I } & 2010 & 0.0076 & - & 0.023 & 0.0028 & - & 0.0067 & 5.3 \\
\hline & & 2013 & 0.0029 & - & 0.01 & - & 0.0005 & 0.0022 & 2.0 \\
\hline & & 2016 & - & - & - & - & - & - & - \\
\hline \multirow{3}{*}{5} & \multirow{3}{*}{ Gulistan - II } & 2010 & 0.0071 & - & 0.016 & 0.0021 & - & 0.0046 & 5.3 \\
\hline & & 2013 & 0.016 & 0.000008 & 0.0039 & 0.0041 & 0.003 & 0.0082 & 1.0 \\
\hline & & 2016 & 0.0026 & 0.000018 & 0.004 & 0.0023 & 0.00028 & 0.0018 & 2.1 \\
\hline \multirow{3}{*}{6} & \multirow{3}{*}{ Mirzachul } & 2010 & 0.0082 & - & 0.0024 & 0.0029 & - & 0.0004 & 4.0 \\
\hline & & 2013 & 0.0036 & 0.00003 & 0.0048 & 0.003 & 0.00009 & 0.0073 & 1.8 \\
\hline & & 2016 & 0.0035 & 0.000009 & 0.015 & 0.002 & 0.0004 & 0.0027 & 2.0 \\
\hline
\end{tabular}

\subsection{Groundwater use}

In the provincial economy, groundwater resources are used for drinking, industrial and technical water, land irrigation and are extracted through vertical wells. Water discharged through vertical wells is directed to open canals or to main canals through pipes. The proximity of the provincial groundwater to the surface layer makes vertical wells widely used. The average depth of these wells is $20-50$ meters.

In 2011-2017, the maximum volume of GWR water used in the provincial economy was $701,440 \mathrm{~m}^{3} /$ day in 2011 and the minimum in 2013 was $534,360 \mathrm{~m}^{3} /$ day. In the years following 2013, the consumption of groundwater used in the economy increased.

During the study years, the maximum amount of water used as a source of drinking water from GWRs was $196,350 \mathrm{~m}^{3} /$ day in 2011 , the minimum in 2016 was $164,390 \mathrm{~m}^{3} /$ day, the maximum amount of water used for industrial and technical purposes was 12,660 $\mathrm{m}^{3} /$ day in 2017 , and the minimum amount in 2016 was $10,730 \mathrm{~m}^{3} /$ day, the maximum amount of water used in agriculture in 2015 was $100,880 \mathrm{~m}^{3} /$ day, and the minimum amount was $91,830 \mathrm{~m}^{3} /$ day in 2012 . The maximum amount of groundwater discharged through vertical wells was $379,180 \mathrm{~m}^{3} /$ day in 2012 , and the minimum was $237,920 \mathrm{~m}^{3} /$ day in 2013 .

Between 2011 and 2017, the least amount of groundwater was used for industrial and technical water purposes. This is due to the fact that the number of industrial enterprises and technical water facilities in the province is lower than in other provinces. Due to the 
presence of groundwater levels in the irrigated areas of the province up to 1.0-1.5 meters, $95 \%$ salinity of the province's WIFs $[49,50]$, groundwater is located close to the surface layer, their level is reduced through wells, to prevent swamping. That is why most of the groundwater in the province is discharged through vertical wells. The distribution of groundwater used in the provincial economy in 2011-2017 to GWR is given in Table 2. This table shows that the amount of groundwater discharged through vertical wells in all GWRs other than the Syrdarya GWR is greater than the amount of groundwater used for other purposes.

The high rates of water used as a source of drinking water correspond to the Syrdarya GWR (Table 2). This is due to the large population in the mining area, the presence of a large number of water users and the consequent increase in water consumption.

Table 2. Distribution of groundwater used in the provincial economy in 2011-2017 to GWR

\begin{tabular}{|c|c|c|c|c|c|c|}
\hline \multirow[b]{2}{*}{$\#$} & \multirow[b]{2}{*}{ GWR names } & \multirow[b]{2}{*}{ Year } & \multicolumn{4}{|c|}{ Groundwater consumption, ' $000 \mathrm{~m} 3 /$ day } \\
\hline & & & 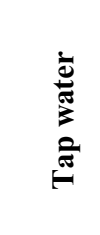 & 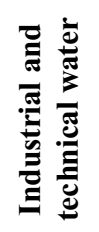 & 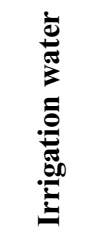 & D \\
\hline \multirow{7}{*}{1} & \multirow{7}{*}{ Khavas } & 2011 & 32.83 & 2.8 & 60 & 124.15 \\
\hline & & 2012 & 30.51 & 2.72 & 60 & 124.15 \\
\hline & & 2013 & 34.29 & 2.77 & 72.4 & 115.8 \\
\hline & & 2014 & 32.94 & 2.17 & 60 & 130 \\
\hline & & 2015 & 34 & 2.17 & 60 & 130 \\
\hline & & 2016 & 24.12 & 2.07 & 60 & 130.8 \\
\hline & & 2017 & 29.43 & 2.2 & 60 & 132 \\
\hline \multirow{7}{*}{2} & \multirow{7}{*}{ Sirdarya } & 2011 & 105.65 & 3.76 & 20.6 & 73.22 \\
\hline & & 2012 & 99.47 & 4.56 & 20.7 & 72.42 \\
\hline & & 2013 & 102.21 & 4.57 & 14.69 & 52.34 \\
\hline & & 2014 & 83.84 & 5.45 & 30.8 & 43.63 \\
\hline & & 2015 & 89.88 & 5.5 & 30.8 & 43.43 \\
\hline & & 2016 & 93.58 & 4.75 & 30.7 & 43.43 \\
\hline & & 2017 & 111.83 & 7 & 29.8 & 43.53 \\
\hline \multirow{7}{*}{3} & \multirow{7}{*}{ Central } & 2011 & 57.12 & 4.99 & 11.33 & 186.54 \\
\hline & & 2012 & 53.3 & 4.29 & 11.13 & 164.91 \\
\hline & & 2013 & 53.45 & 4.89 & 6.17 & 61.97 \\
\hline & & 2014 & 47.63 & 4.01 & 10 & 84.96 \\
\hline & & 2015 & 47.63 & 4.01 & 10 & 84.96 \\
\hline & & 2016 & 45.69 & 3.81 & 10 & 86.16 \\
\hline & & 2017 & 45.09 & 3.46 & 10 & 121 \\
\hline \multirow{7}{*}{4} & \multirow{7}{*}{ Dustlik } & 2011 & 0.75 & - & - & 17.7 \\
\hline & & 2012 & 0.75 & - & - & 17.7 \\
\hline & & 2013 & 1 & - & - & 7.81 \\
\hline & & 2014 & 1 & - & - & 8.83 \\
\hline & & 2015 & 1 & - & - & 8.83 \\
\hline & & 2016 & 1 & - & - & 8.83 \\
\hline & & 2017 & 1.1 & - & - & 8.83 \\
\hline
\end{tabular}


We can see that the dynamics of water consumption in Central GWR is similar to the dynamics of water consumption in Khavas GWR. Water was extracted through the most vertical wells and was used for the least industrial and technical purposes (Table 2).

Dustlik GWR water differs from other GWR in the province only in that it is discharged through a source of drinking water and vertical wells, and the water consumption is negligible. The water discharged through the vertical wells accounted for $87-96 \%$ of the total water consumption from the field. The rest is used as a source of drinking water.

During the experimental years, groundwater was also widely used in agriculture. This is due to the fact that about $67.2 \%$ of the total land area of the province is irrigated.

As of January 2018, the total amount of groundwater used in the economy in the province was $605,330 \mathrm{~m}^{3} /$ day. The largest amount of groundwater extracted through vertical wells was $305,370 \mathrm{~m}^{3} /$ day. The total number of groundwater users in Sirdarya province was 420, of which in Syrdarya district (the maximum) was 119 or $28.33 \%$, and in Sardoba district (the minimum) was 7 or $1.7 \%$ (Fig. 8). The average annual level of groundwater use in the province was $605,330 \mathrm{~m}^{3} /$ day. Groundwater was used the most in Khavas district at $223,100 \mathrm{~m}^{3} /$ day $(36.86 \%)$ and the lowest in Sardoba district at 2,380 $\mathrm{m}^{3} /$ day $(0.39 \%)$ (Fig. 8$)$.

In the sustainable use of groundwater resources, it is important to pay attention to the purposes of water use and the type of users. In Syrdarya district, 119 water users consumed an average of $80,800 \mathrm{~m}^{3} /$ day, in Khavas district 103 water users consumed $223,100 \mathrm{~m}^{3} /$ day, and in Gulistan district, which has 59 water users, consumed 113,120 $\mathrm{m}^{3} /$ day. It can be seen that water consumption depends not on the number of users, but on their type and purpose of use (Fig. 8).

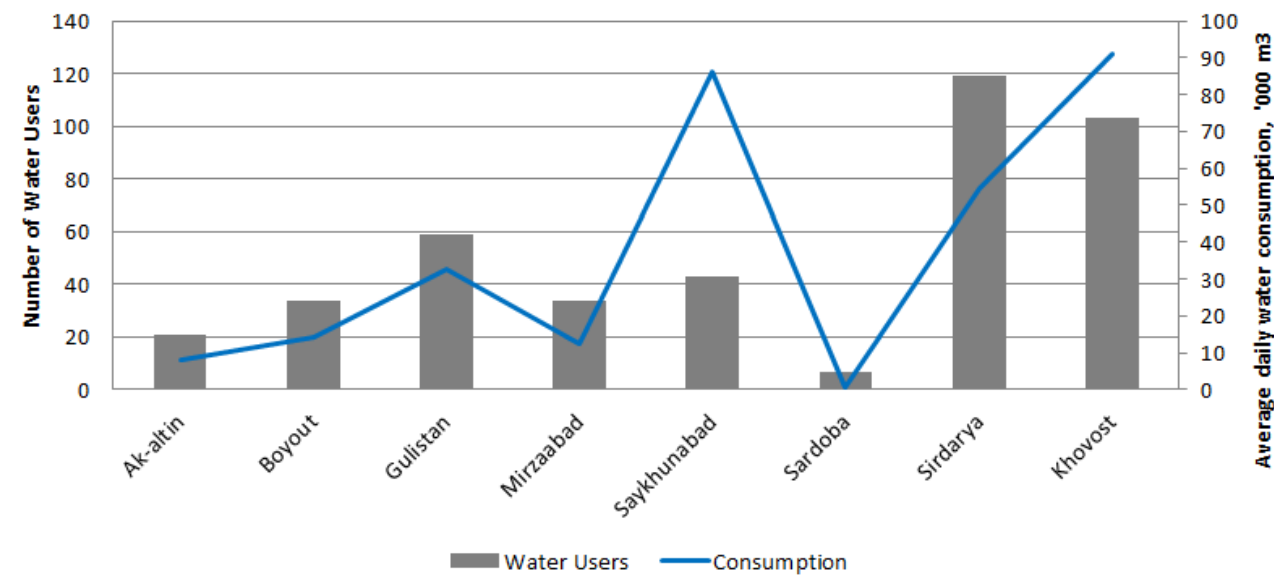

Fig. 8. Number of groundwater users and water consumption in the districts of Sirdarya province.

As of January 2018, the highest level of groundwater use in the economy of Sirdarya province was in Khavas district $-223,100 \mathrm{~m}^{3} /$ day, followed by Gulistan district $-113,120$ $\mathrm{m}^{3} /$ day, Sayhunabad district $-93,430 \mathrm{~m}^{3} /$ day, Syrdarya district $-80,800 \mathrm{~m}^{3} /$ day, Boyovut district $-43,680 \mathrm{~m}^{3} /$ day, Mirzaabad district $-36,990 \mathrm{~m}^{3} /$ day, Okoltin district $-11,830$ $\mathrm{m}^{3} /$ day, and the lowest amount, Sardoba district - 2,380 $\mathrm{m}^{3} /$ day (Fig. 9). 


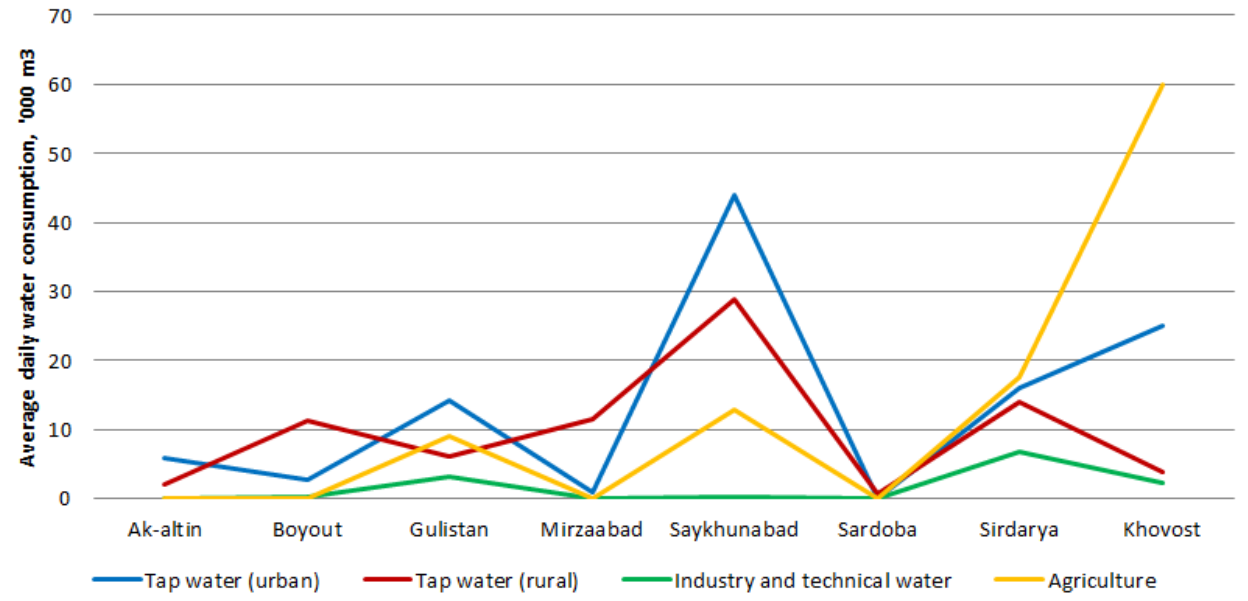

Fig. 9. Level of groundwater use in the economy of the province.

\section{Conclusions}

The province's GWR is trans-geographical in nature, forming part of the country's water resources and used for drinking, agricultural and livestock development. During the study years, groundwater mineralization ranged from $14.0-98.0 \mathrm{mg} / \mathrm{l}$ in $2010-2013$, to $4.0-188.0$ $\mathrm{mg} / \mathrm{l}$ in 2013-2016, and to a hardness of $0.1 \%$ in 2010-2013. $1.0 \mathrm{mg}$-eq/1 and between 2013 and 2016 ranged from 0.1 to $1.4 \mathrm{mg}$-eq/1.

Beshbulak WIF water had the lowest content of chemical elements and Sardoba - I WIF water had the highest content of chemical elements. Although the groundwater quality indicators of the province have changed over time and distance during the study years, the content of harmful heavy metals such as $\mathrm{Cu}, \mathrm{Be}, \mathrm{Mo}, \mathrm{As}, \mathrm{Pb}$, Se and $\mathrm{Sr}$ did not exceed the $\mathrm{PN}$ and play an important role in providing clean drinking water to the population of the province.

Among the provincial GWRs, the Syrdarya GWR is located in the Syrdarya river basin and is the richest source of groundwater. The supply of drinking water to the population of the province $(50-60 \%)$ falls on this GWR. The province's groundwater is discharged in large quantities through vertical wells and directed to farm and main canals. The water discharged through the vertical wells accounts for $87-96 \%$ of the total water consumption from the field.

Due to the fact that the provincial GWRs are a reliable source of drinking water for the population and the growth of the province's population, the development of agriculture and industry, it is necessary to improve the integrated monitoring system using remote sensing and satellite data. Given the transboundary nature of the province's groundwater, it will be necessary to cooperate with neighboring countries in their use and protection.

\section{References}

1. R. Kulmatov, Environmental Problems of Central Asia and their Economic, Social and Security Impacts, 15-30 (2008)

2. Y. Liu, P. Wang, H. Ruan, T. Wang, J.Yu, Y. Cheng, R. Kulmatov, Water, 12(8), 2101 (2020)

3. S.M. Gorelick, C. Zheng, Water Resources Research, 51(5), 3031-3051 (2015) 
4. UNESCO-IGRAC, Transboundary Aquifers of the World Map (2020)

5. R. Kulmatov, A. Taylakov, S. Khasanov, Environmental Science and Pollution Research, 28(10), 12245-12255 (2021)

6. R.A. Kulmatov, A.A. Kist, IND. LAB, 44(12), 1689-1692 (1978)

7. B. Kløve, P. Ala-Aho, G. Bertrand, J. Gurdak, H. Kupfersberger, J. Kværner, Journal of Hydrology, 518, 250-266 (2014)

8. R. Taylor, B. Scanlon, P. Doell, M. Rodell, R. Van Beek, Y. Wada, H. Treidel, Nature climate change, 3(4), 322-329 (2013)

9. V.M. Emets, R.A. Kulmatov, Doklady Biological Sciences, 271(1-6), 370-372 (1983)

10. R.A. Kulmatov, S.A. Adilov, S. Khasanov, IOP Conference Series: Earth and Environmental Science, 614(1), 012149 (2020)

11. B. Alikhanov, M. Juliev, S. Alikhanova, I. Mondal, Groundwater for Sustainable Development, 12, 100548 (2021)

12. E. Lee, R. Jayakumar, S. Shrestha, Z. Han, Journal of Hydrology: Regional Studies, 20, 103-115 (2018)

13. Y. Eckstein, G. Eckstein, Groundwater, 43(5), 679-690 (2005)

14. R. Kulmatov, J. Mirzaev, J. Abuduwaili, B. Karimov, Journal of Arid Land, 12(1), 90$103(2020)$

15. T. Gleenson, K. Befus, S. Jasechko, E. Luijendijk, M. Cardenas, Nature Geoscience, 9(2), 161-167 (2016)

16. A. Stone, M. Lanzoni, P. Smedley, Water science, policy, and management: A global challenge, 29-54 (2019)

17. I. Zekster, A. Karimova, A. Chetverikova, Water Resources, 42(4), 351-366 (2015)

18. Y. Peng, F.D. Li, N. Xu, R. Kulmatov, K.C. Gao, G.Q. Wang, Y.Y. Zhang, Y.F. Qiao, Y.H. Li, H. Yang, S. Hao, Q. Li, S. Khasanov, Chinese Journal of Eco-Agriculture, 29(2), 312-324 (2021)

19. B. Abdullaev, R.A. Kulmatov, A.A. Kist, Industrial Laboratory (USSR) (English translation of Zavodskaya Laboratoriya), 54(7), 710-713 (1989)

20. W.M. Edmunds, P. Shand, Natural groundwater quality, 488 (Wiley, 2008)

21. B. Bai, Y. Cheng, Z. Jiang, C. Zhang, Journal of Groundwater Science and Engineering, 5(1), 44-52 (2017)

22. R.A. Kulmatov, V.S. Savenko, N. Dalonov, Geochemistry International, 29(5), 140148 (1992)

23. S.R. Shrestha, G. Tripathi, D. Laudari, Groundwater of South Asia, 169-193 (2018)

24. S. Mirzaev, Uzbek Geological Journal, 2, 148-181 (1965)

25. R. Kulmatov, C. Opp, M. Groll, D. Kulmatova, Assessment of water quality of the transboundary Zarafshan River in the territory of Uzbekistan, 5(1), 10 (2013)

26. P. Leng, Q. Zhang, F. Li, R. Kulmatov, G. Wang, Y. Qiao, J. Wang, Y. Peng, C. Tian, N. Zhu, H. Hirwa, S. Khasanov, Environmental Pollution, 284, 117405 (2021)

27. I. Aslanov, S. Khasanov, Y. Khudaybergenov, M. Groll, Ch. Opp, F. Li, E. Ramirez Del-Valle, E3S Web of Conferences, 227, 02005 (2021)

28. J. Qi, S. Pueppke, R. Kulmatov, T. Bobushev, S. Tao, T. Yespolov, X. Chen, Landscape Dynamics of Drylands across Greater Central Asia: People, Societies and Ecosystems, 71-85 (2020) 
29. Y. Yu, Y. Pi, X. Yu, Z. Ta, L. Sun, M. Disse, R. Yu, Journal of Arid Land, 11(1), 1-14 (2019)

30. J. Margat, J. Van der Gun, Groundwater around the world: a geographic synopsis, 421 (2013)

31. S. Yang, X. Yu, J. Ding, F. Zhang, F. Wang, Y. Ma, Acta Geographica Sinica, 72(1), 79-93 (2017)

32. R. Kulmatov, S. Khasanov, S. Odilov, F. Li, Water, Air, and Soil Pollution, 232(5), $216(2021)$

33. S. Rakhmatullaev, F. Huneau, H. Celle-Jeanton, P. Le Coustumer, M. Motelica-Heino, M. Bakiev, Environmental Earth Sciences, 68(4), 985-998 (2013)

34. S. Rakhmatullaev, F. Huneau, J. Kazbekov, P. Le Coustumer, J. Jumanov, B. El Oifi, Z. Hrkal, Environmental Earth Sciences, 59(6), 1183-1193 (2010)

35. State Committee for Statistics, Statistical data on water resources of Uzbekistan (2020)

36. U. Abdullaev, G. Khasankhanova, S. Myagkov, N. Agaltseva, A report of the UNDP project under the seventh goal (Publication in support of the Millennium Development Goals), 26 (2007)

37. A. Karimov, V. Smatkhin, A. Mavlonov, V. Borisov, A report of IWMI, 151, 49 (2013)

38. S. Mirzaev, Groundwater reserves of Uzbekistan, 198 (Fan Press, Tashkent, 1974)

39. S. Rakhmatullaev, F. Huneau, J. Kazbekov, H. Celle-Jeanton, M. Motelica-Heino, P. Le Coustumer, J. Jumanov, Open Geosciences, 4(1), 67-80 (2012)

40. I. Aslanov, U. Mukhtorov, R. Mahsudov, U. Makhmudova, S. Alimova, L. Djurayeva, O. Ibragimov, E3S Web of Conferences, 258, 04012 (2021)

41. A. Khamzina, R. Sommer, J. Lamers, P. Vlek, Agricultural and Forest Meteorology, 149(11), 1865-1874 (2009)

42. J.X. Djumanov, J.J. Jumanov, Z.T. Karabaeva, The American Journal of Applied sciences, 3(02), 84-94 (2021)

43. Hydrometeorological Service of Uzbekistan, Long-term climate data of Uzbekistan, online open-access data (2020)

44. B. Matyakubov, G. Goziev, U. Makhmudova, E3S Web of Conferences, 258, 03022 (2021)

45. C. Kurzman, Journal for Critical Studies of the Middle East, 8(15), 77-98 (1999)

46. R. Ismailovich, M. Pulatovich, U. Fayzullaevna, Annals of the Romanian Society for Cell Biology, 430-436 (2021)

47. A. Karimov, V. Smakhtin, A. Mavlonov, V. Borisov, I. Gracheva, F. Miryusupov, A. Karimov, Journal of Hydrologic Engineering, 20(3), B5014004 (2015)

48. A.J. Bednar, J.R. Garbarino, M.R. Burkhardt, J.F. Ranville, T. Wildeman, Water Research, 38(2), 355-364 (2004)

49. S. Khasanov, S. Adilov, R. Kulmatov, Irrigation and Melioration, 2020(3), 20-29 (2020)

50. M. Groll, R. Kulmatov, N. Mullabaev, C. Opp, D. Kulmatova, Environmental Earth Sciences, 75(10), 921 (2016) 